\title{
Screening and identification of human ZnT8-specific single-chain variable fragment (scFv) from type 1 diabetes phage display library
}

\author{
Qian $\mathrm{Wu}^{1 \dagger}$, Xiaodong Wang ${ }^{1 \dagger}$, Yong $\mathrm{Gu}^{1 \dagger}$, Xiao Zhang ${ }^{2}$, Yao Qin ${ }^{1}$, Heng Chen ${ }^{1}$, \\ Xinyu Xu ${ }^{1}$, Tao Yang ${ }^{1} \&$ Mei Zhang* ${ }^{1}$ \\ ${ }^{1}$ Department of Endocrinology, The First Affiliated Hospital of Nanjing Medical University, Nanjing 210029, China; \\ ${ }^{2}$ Key Laboratory of Antibody Technique, Ministry of Health, Nanjing Medical University, Nanjing 210029, China
}

Received April 16, 2016; accepted May 12, 2016; published online June 8, 2016

\begin{abstract}
Zinc transporter 8 (ZnT8) is a major autoantigen and a predictive marker in type 1 diabetes (T1D). To investigate ZnT8-specific antibodies, a phage display library from T1D was constructed and single-chain antibodies against ZnT8 were screened and identified. Human T1D single-chain variable fragment $(\mathrm{scFv})$ phage display library consists of approximately $1 \times 10^{8}$ clones. After four rounds of bio-panning, seven unique clones were positive by phage ELISA. Among them, C27 and C22, which demonstrated the highest affinity to ZnT8, were expressed in Escherichia coli Top10F' and then purified by affinity chromatography. C27 and C22 specifically bound ZnT8 N/C fusion protein and ZnT8 C terminal dimer with one Arg325Trp mutation. The specificity to human islet cells of these scFvs were further confirmed by immunohistochemistry. In conclusion, we have successfully constructed a T1D phage display antibody library and identified two ZnT8-specific scFv clones, C27 and C22. These ZnT8-specific scFvs are potential agents in immunodiagnostic and immunotherapy of T1D.
\end{abstract}

Zinc transporter 8 (ZnT8), phage display, single-chain variable fragment (scFv), type 1 diabetes (T1D)

Citation: Wu, Q., Wang, X., Gu, Y., Zhang, X., Qin, Y., Chen, H., Xu, X., Yang, T., and Zhang, M. (2016). Screening and identification of human ZnT8-specific single-chain variable fragment $(\mathrm{scFv})$ from type 1 diabetes phage display library. Sci China Life Sci 59, 686-693. doi: $10.1007 / \mathrm{s} 11427-016-5077-7$

\section{INTRODUCTION}

Zinc is an essential element for all cells and plays an important role in insulin secretion. Zinc transporter (ZnT) and $\mathrm{Zrt} /$ Irt-like protein (ZIP) are two main components that maintain zinc homeostasis in the body (Overbeck et al., 2008). The proteins of ZnT family play a role as zinc ion diffusion facilitators, which allow diffusion of zinc ion across biological membrane. Among ZnT family members, Chimienti et al. first showed that ZnT8, encoded by the gene SLC30A8, was the most expressed transporter in hu-

$\dagger$ Contributed equally to this work

*Corresponding author (email: zhangmei@njmu.edu.cn) man pancreas and further identified that ZnT8 was exclusively expressed in secretory granules of islet $\beta$ cells (Chimienti et al., 2004; Chimienti et al., 2006). The overexpression of ZnT8 in islet cells stimulates zinc accumulation and enhances glucose-stimulated insulin secretion compared with control cells (Chimienti et al., 2006). These findings showed that ZnT8 is essential for zinc accumulation and the storage, secretion, and the action of insulin.

Type 1 diabetes (T1D) is an autoimmune disease resulting from the destruction of islet $\beta$ cells by immune responses. The immune cells attack a series of autoantigens expressed in $\beta$ cells. These autoantigens were identified, including insulin, $65-\mathrm{kD}$ isoform of glutamic acid decarboxylase (GAD), tyrosine phosphatase and ZnT8. Among them, 
ZnT8 was observed to be one of the major autoantigens and a predictive marker in risk groups before onset of the disease. Wenzlau et al. followed the individuals from birth to T1D onset and they found that ZnT8 antibodies (ZnT8A) appeared as early as 2 years of age and showed increasing levels and prevalence persisting to disease onset (Wenzlau et al., 2009; Wenzlau et al., 2007). Some suggested a strong inverse relationship between the age of T1D onset and the prevalence of ZnT8A (Kawasaki, 2012). Our study demonstrated that ZnT8 as a novel autoantigen containing many immunodominant epitopes, which were recognized in type 1 diabetes patients (Xu et al., 2015). The detection of antibodies and $\mathrm{CD}^{+} \mathrm{T}$ cells against $\mathrm{ZnT} 8$ is an important way for the prediction and diagnosis of T1D. Antigen-specific therapy which targets to ZnT8 could be a potential way in preventing and/or delaying the progression of T1D in the future (Dang et al., 2011).

Antibody research has developed over a century. Kohler and Milstein first created B lymphocyte hybridoma technology in 1975 (Kohler and Milstein, 1975). On the one hand, the antibodies generated from mouse were immunogenic to human, they were easy to generate human anti-mouse antibody (HAMA) (Hasholzner et al., 1997) and allergic reaction (Richter and Daquillard, 1980). On the other hand, such antibodies were macromolecules and were difficult to cross the membrane. So the applications of such antibodies have been limited in the field of disease treatment. Now, some whole molecular antibodies against ZnT8 have been produced through $\mathrm{B}$ lymphocyte hybridoma technology (Ustinova et al., 2013). But due to the disadvantages mentioned above, the applications of such antibodies were limited.

Since 1980s, phage display was established for the study of protein-protein and protein-DNA interaction (McCafferty et al., 1990). Now, phage display is a powerful technique for isolating specific antibodies against a given antigen. Among these whole molecular antibodies, $\mathrm{scFv}$ is only $1 / 6$ of the whole antibody; small molecular weight makes it possible to penetrate between blood vessels or tissue barriers more easily. Other advantages of scFv are: more stable structure, shorter half-life, and with no constant fragment $(\mathrm{Fc})$, which may cause the adverse impacts.

Chimeric antigen receptors (CARs) are emerging as powerful tools for modified $\mathrm{T}$ cell specificity and function in immunotherapy (Brenner and Heslop, 2010), in which T cells are genetically engineered to express extracellular $\mathrm{scFv}$ antigen-binding domains fused to intracellular signaling domains (Cheadle et al., 2014). CARs were applied in immunology and got some interesting results. Tregs expressing CARs against specific antigens have been tested and their functions have been verified in vitro and in vivo (Elinav et al., 2009; Fransson et al., 2012; MacDonald et al., 2016), which provided a basis to develop the immunotherapy for autoimmune disease by CAR-Treg.

To further investigate and identify the ZnT8-specific an- tibodies in T1D, we constructed a $\mathrm{scFv}$ phage display library of T1D and then isolated the positive clones against $\mathrm{ZnT}$ 8 protein which may provide a novel way to immunodiagnosis or immunotherapy of T1D.

\section{RESULTS}

\section{Production and identification of the recombinant ZnT8 protein}

The ZnT8 N/C fusion construct ( $550 \mathrm{bp})$ and the ZnT8 C terminal dimer construct ( $\sim 650 \mathrm{bp})$ gene were amplified and successfully inserted into pcold II vector (Figure 1). The inserted DNA was confirmed by sequencing.

The estimated molecular weight of N/C fusion protein and $\mathrm{C}$ terminal dimer were about $20 \mathrm{kD}$ and $25 \mathrm{kD}$ respectively. After purification, the protein showed distinct bands on SDS-PAGE corresponding to the expected size (Figure 2 ). The results indicated that the recombinant proteins were successfully expressed and purified.

The ELISA assay of the N/C fusion protein to the commercial antibodies showed that the purified and denatured ZnT8 protein has bioactivity which confirmed that it could be used to screen ZnT8 specific antibodies (Figure 3).

\section{Construction of phage display scFv library from T1D patients' peripheral blood}

There were 31 individuals among the 50 volunteers showed positive responses to ZnT8. After RT-PCR and overlapping PCR, scFv gene ( 750 bp) was successfully assembled (Figure 4). After inserted $\mathrm{scFv}$ DNA fragments to the pcomb3XSS with $S f i$ I and transformed into E. coli XL1Blue, a phage display library containing $1.0 \times 10^{8}$ clones was successfully constructed.

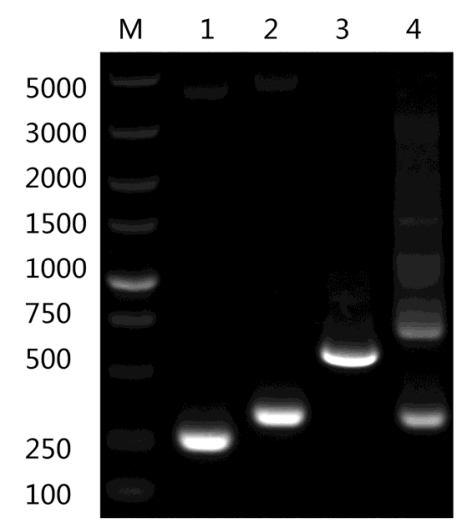

Figure 1 Construction of recombinant ZnT8 gene. N terminal (1-74 aa) and $\mathrm{C}$ terminal (268-369 aa) gene were amplified from the plasmid containing full length of human ZnT8 (Slc30A8) ORF. N/C fusion gene was amplified by overlap-PCR. C terminal dimer gene was amplified from the plasmid donated by Barbara Davis Center. M, DNA ladder Marker; lane 1, $\mathrm{N}$ terminal PCR product amplified by primer ZF and LR, ( 250 bp); lane 2, $\mathrm{C}$ terminal PCR product amplified by primer LF and CR, ( 350 bp); lane 3, N/C fusion PCR product amplified by primer ZF and CR, ( 550 bp); lane 4, $\mathrm{C}$ terminal dimer PCR product amplified by primer CF and CR, $(\sim 650 \mathrm{bp})$. 

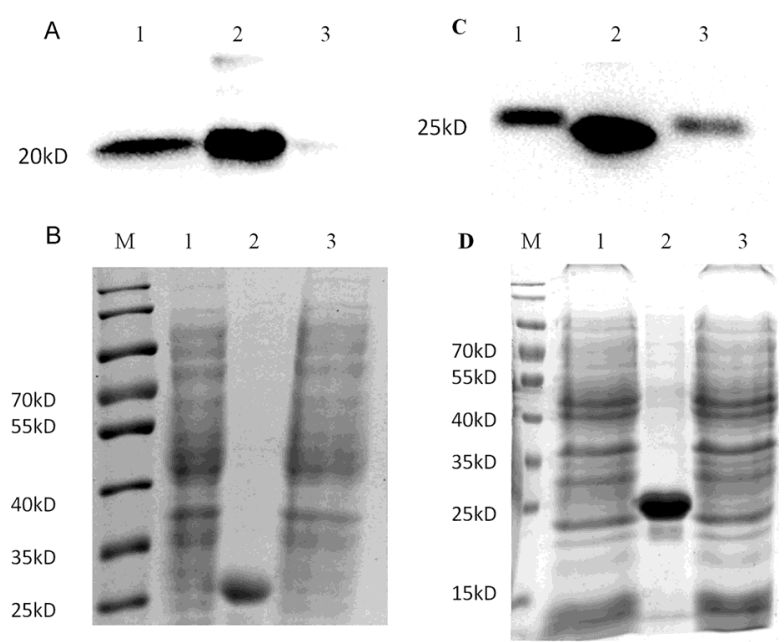

Figure 2 Purification and identification recombinant protein of ZnT8. Proteins were transferred onto PVDF after electrophoresis in $12 \%$ SDS-PAGE. HRP-conjugated anti-His antibody was used to detect the recombinant protein. A, Western blotting analyze of N/C fusion protein (lane 1, Protein before purification; lane 2, Protein after purification; lane 3 , flow pass during purification). B, SDS-PAGE analyze of N/C fusion protein (M, protein ladder marker, lane 1, Protein before purification; lane 2, Protein after purification; lane 3 , flow pass during purification). C, Western blotting analyze of $\mathrm{C}$ terminal dimer (lane 1 , Protein before purification; lane 2, Protein after purification; lane 3, flow pass during purification). D, SDS-PAGE analyze of $\mathrm{C}$ terminal dimer protein (M, protein ladder marker, lane 1, Protein before purification; lane 2, Protein after purification; lane 3, flow pass during purification). The estimated molecular weight of N/C fusion protein was about $20 \mathrm{kD}$, The estimated molecular weight of $\mathrm{C}$ terminal dimer protein was about $25 \mathrm{kD}$.

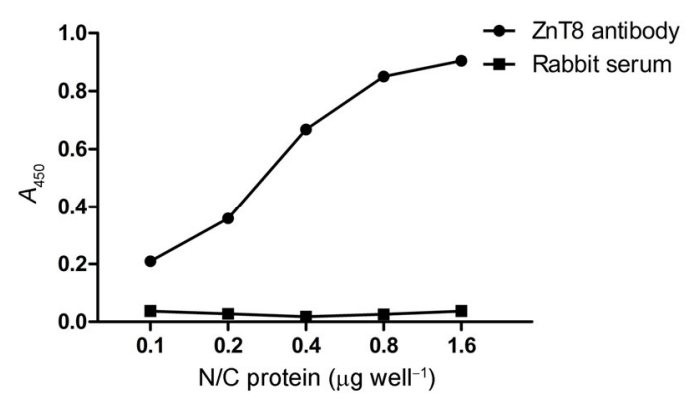

Figure 3 Binding ability of N/C fusion protein to ZnT8A measured by ELISA. ZnT8 N/C fusion protein was coated on the ELISA plate with the concentration varied from $1.6 \mu \mathrm{g}$ well ${ }^{-1}$ to $0.1 \mu \mathrm{g}$ well $^{-1}$ by serial dilution. Commercial rabbit anti-human ZnT8A was used as primary antibody, HRP-conjugated anti-rabbit IgG was used as secondary antibody. Rabbit serum was used as negative control.

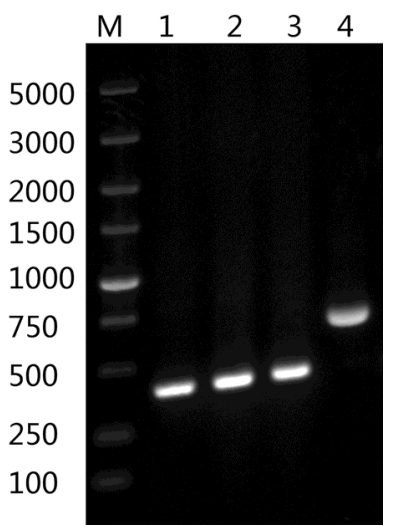

Figure 4 Construction of scFv phage display library from T1D. V $\lambda$, Vא, VH gene were amplified by a group of human specific constant region primers. ScFv gene was amplified by overlap-PCR. M, Marker; lane 1, V $\lambda$

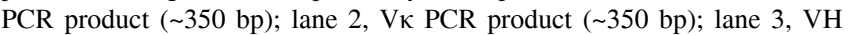
PCR product ( $\sim 50 \mathrm{bp})$; lane 4 , scFv PCR product ( $\sim 800 \mathrm{bp})$.

\section{Production and identification of anti-ZnT8 scFv}

After four rounds of bio-panning, enrichment of high affinity $\mathrm{scFv}$ was obtained. The titers of the eluted phages of each round of panning were showed in Table 1. A 32-fold increase in the ratio of outputted vs inputted phage titer, expressed as the enrichment factor, was observed from round 3 to round 4 (Table 1 ).

ScFvs were selected from 160 randomly picked clones by phage ELISA. Among them, eleven clones showed high positivity and seven different scFvs were obtained (Figure $5)$. They all contained $\sim 750 \mathrm{bp}$ scFv confirmed by DNA sequencing. The affinity of scFv C27 and C22 were the highest among these positive clones. Therefore, we chose them as our major scFvs for further experiments.

After expression and purification, both $\mathrm{C} 27$ and $\mathrm{C} 22$ showed a single band with the expected size ( $30 \mathrm{kD})$ (Figure 6).

\section{Bioactivity of anti-ZnT8 scFv}

As shown in Figure 7, ZnT8 N/C fusion protein showed a band $\sim 20 \mathrm{kD}$ with $\mathrm{C} 27$ and $\mathrm{C} 22 \mathrm{scFv}$, which is the predicted molecular weight.

The affinity assay showed that both $\mathrm{C} 27$ and $\mathrm{C} 22 \mathrm{scFv}$ bound to N/C fusion protein with high affinity, the $\mathrm{kD}(\mathrm{M})$ was $5.397 \times 10^{-8}$ and $5.953 \times 10^{-8}$ respectively (Figure 8).

Table 1 Enrichment of phage display library from ZnT8 N/C fusion protein ${ }^{\text {a) }}$

\begin{tabular}{ccccc}
\hline Round & Iuputted & Outputted & Yield (\%) & Enrichment (Yield n/Yield n-1) \\
\hline 1 & $1 \times 10^{13}$ & $4 \times 10^{5}$ & $4 \times 10^{-6}$ & - \\
2 & $2.5 \times 10^{12}$ & $8 \times 10^{5}$ & $3.2 \times 10^{-5}$ & 8.0 \\
3 & $1.8 \times 10^{12}$ & $1.4 \times 10^{6}$ & $7.8 \times 10^{-5}$ & 2.4 \\
4 & $1 \times 10^{12}$ & $2.5 \times 10^{7}$ & $2.5 \times 10^{-3}$ & 32 \\
\hline
\end{tabular}

a) Yield $(\%)=$ outputted phages $(\mathrm{pfu}) \times 100 /$ inputted phages $(\mathrm{pfu})$. 


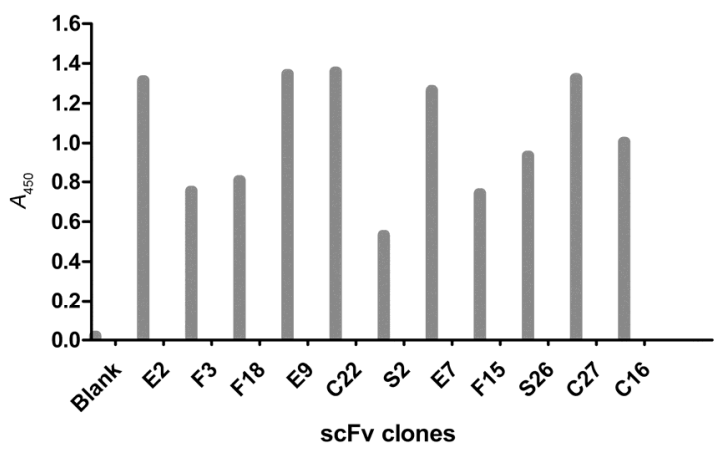

Figure 5 Binding ability of $\mathrm{scFv}$ antibodies to ZnT8 N/C fusion protein by phage-ELISA. The 11 clones shown in the figure were selected based on high positive binding to recombinant ZnT8 protein.
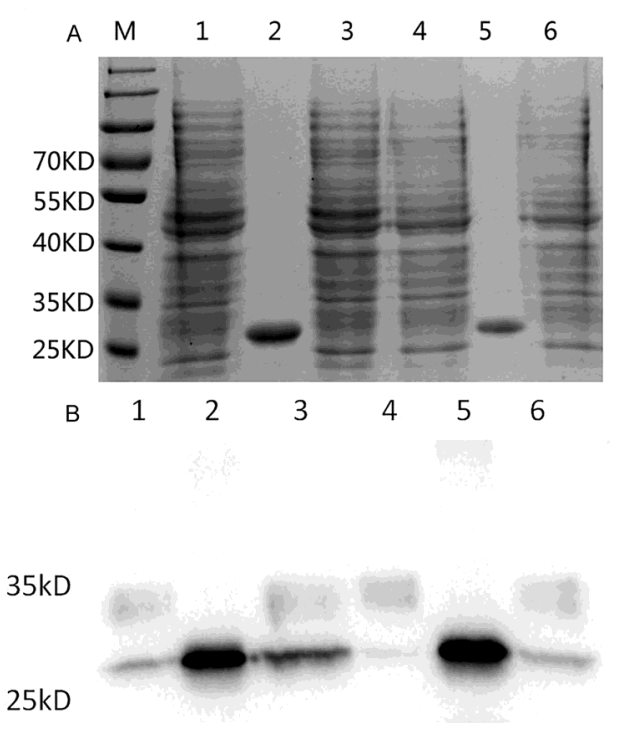

Figure 6 Purification and identification of scFv. Proteins were transferred onto PVDF after electrophoresis in $12 \%$ SDS-PAGE. HRP-conjugated anti-His antibody was used to detect the recombinant protein. A, SDS-PAGE analyze of $\mathrm{scFv}$ (M, Protein ladder marker; lane 1, $\mathrm{scFv}-\mathrm{C} 27$ before purification; lane 2, purified scFv-C27; lane 3, flow pass during scFv-C27 purification; lane 4, scFv-C22 before purification; lane 5, purified $\mathrm{scFv}-\mathrm{C} 22$; lane 6 , flow pass during $\mathrm{scFv}-\mathrm{C} 22$ purification). B, Western blotting analyze of $\mathrm{scFv}(\mathrm{M}$, Protein ladder marker; lane 1, $\mathrm{scFv}-\mathrm{C} 27$ before purification; lane 2, purified $\mathrm{scFv}-\mathrm{C} 27$; lane 3, flow pass during scFv-C27 purification; lane 4, scFv-C22 before purification; lane 5, purified scFv-C22; lane 6 , flow pass during $\mathrm{scFv}-\mathrm{C} 22$ purification).

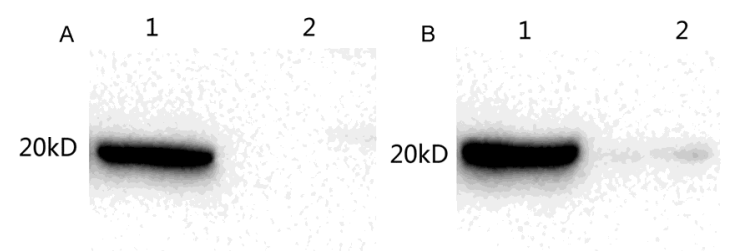

Figure 7 Binding ability of scFv to ZnT8 N/C fusion protein by western blotting analyze. ZnT8 N/C fusion protein was transferred onto PVDF after electrophoresis in $12 \%$ SDS-PAGE, scFv was used as primary antibody, HRP-conjugated anti-HA antibody was used as second antibody. The bacteria transformed with negative plasmid were used as negative control. A, lane 1, N/C fusion protein detected with $\mathrm{scFv}-\mathrm{C} 27$; lane 2, negative control. $\mathrm{B}$, lane $1, \mathrm{~N} / \mathrm{C}$ fusion protein detected with $\mathrm{scFv}-\mathrm{C} 22$; lane 2, negative control.
As shown in Figure 9, the binding capacity of serial diluted $\mathrm{scFv}$ to the $\mathrm{C}$ terminal dimer decreased with the dilution ratio increased, which indicated the renatured scFvs could bind to ZnT8 in a concentration dependent manner. As shown in Figure 10, these two scFvs were specific to human islet cells.

\section{DISCUSSION}

In this study, we first constructed a T1D phage display scFv library containing $1.0 \times 10^{8}$ clones which could be applied for antibody screening. We recruited 50 newly diagnosed T1D patients to ensure the diversity and the wide representativeness of the antibody library. From our phage display library, we can screen all antibodies of T1D, which is valuable for further studies of antibodies in T1D. To our knowledge, the T1D scFv phage display library has neither been established nor been used to screen T1D related antibodies before.

As described in some articles, ZnT8 antigen, encoded by the gene SLC30A8, is a major autoantigen in T1D (Kawasaki, 2012). SLC30A8 gene is located on chromosome 8 at the position q24.11 in human. It contains eight exons, spanning $37 \mathrm{~kb}$, and encoding ZnT8 protein containing 369 amino acids, which has six transmembrane helixes as the other $\mathrm{ZnT}$ proteins (Chimienti et al., 2004; Seve et al., 2004; Weijers, 2010). The autoantibodies against ZnT8 play an important role in the onset and development of T1D. The $\mathrm{N}$ terminal (1-74 aa) and $\mathrm{C}$ terminal (268-369 aa) proteins of ZnT8, located in the extracellular part in insulin secreting vesicles, contain many important epitopes recognized by autoantibodies (Skarstrand et al., 2015; Skarstrand et al., 2013; Wenzlau et al., 2007). As ZnT8 might be one of the key players in mediating both insulin secretion and $\beta$ cell mass in T1D, a thorough understanding of the molecular function of ZnT8A can help us design an immunotherapy to cure T1D. To ensure the diversity of the screened scFv, we chose ZnT8 N/C fusion protein for bio-panning. Since previous studies showed that principal epitopes targeted by ZnT8A were influenced by a single amino acid at position 325 encoded as arginine or tryptophan in T1D, the ZnT8 C terminal dimer with Arg325Trp mutation protein has been proved to possess both specificity and sensitivity to detect ZnT8A (Kawasaki et al., 2014; Kawasaki et al., 2008; Wenzlau et al., 2008). We identified the specificity of scFvs through ZnT8 C terminal dimer with Arg325Trp mutation. Our results showed that both scFv-C27 and scFv-C22 well recognized $\mathrm{C}$ terminal dimer protein, which indicated that these two clones of $\mathrm{scFv}$ isolated in this study were specific to ZnT8 protein. The immunohistochemistry results further confirmed scFv-C27 and scFv-C22 were specific to human islet cells.

In conclusion, we successfully constructed a T1D phage display scFv library, screened and identified ZnT8 specific scFvs, scFv-C27 and scFv-C22. These two clones of scFv 


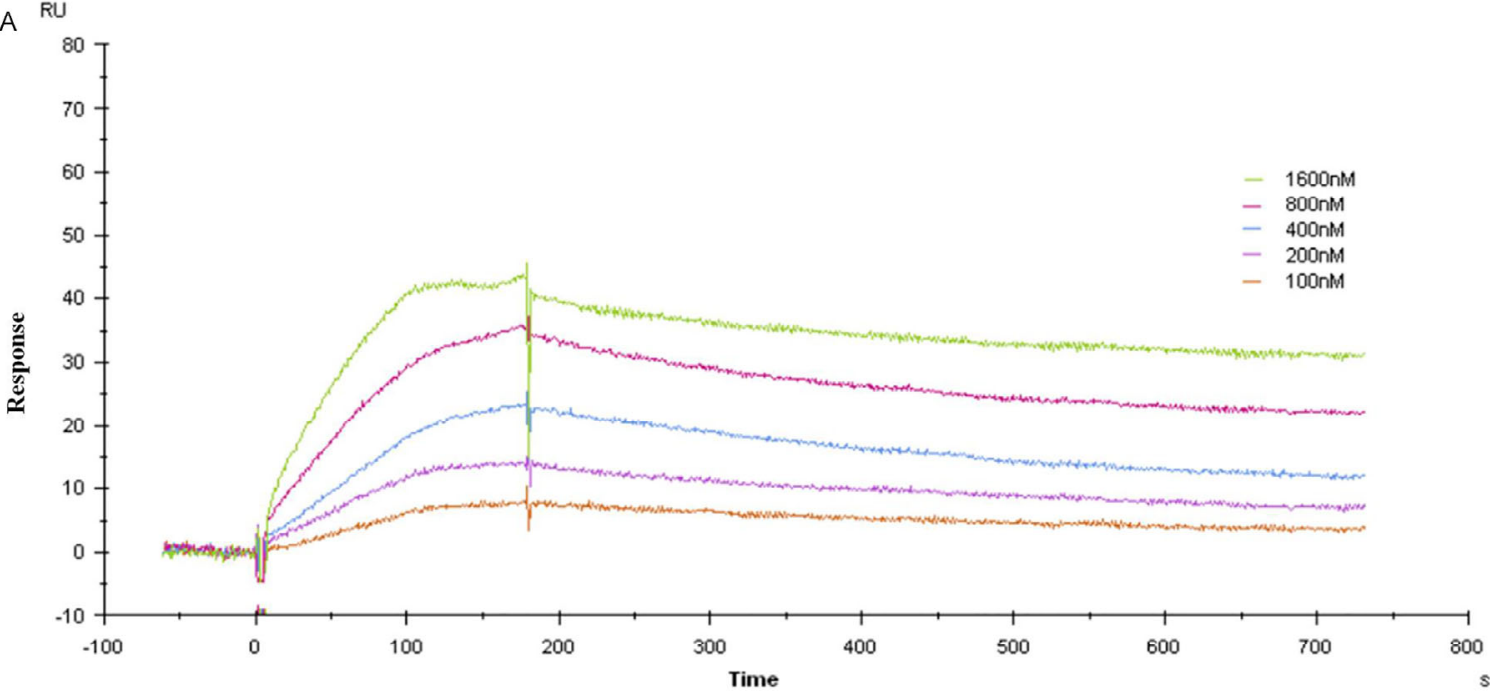

Quality Control Report Residuals Parameters

\begin{tabular}{|c|c|c|c|c|c|c|c|c|c|c|c|}
\hline Curve & ka (1/Ms) & $\operatorname{kd}(1 / \mathrm{s})$ & KD (M) & Rmax (RU) & Conc (M) & tc & Flow (ul/min) & kt (RU/Ms) & RI (RU) & $\mathrm{Chi}^{2}\left(\mathbf{R U ^ { 2 }}\right)$ & U-value \\
\hline & $1.349 E+4$ & $7.283 \mathrm{E}-4$ & $5.397 \mathrm{E}-8$ & & & $3.398 \mathrm{E}+18$ & & & & 5.23 & 2 \\
\hline Cycle: $5100 \mathrm{nM}$ & & & & 84.57 & 1.000E-7 & & 30.00 & $1.056 E+19$ & 0.9696 & & \\
\hline Cycle: $6200 \mathrm{nM}$ & & & & 74.43 & $2.000 E-7$ & & 30.00 & $1.056 E+19$ & 4.199 & & \\
\hline Cycle: $7400 \mathrm{nM}$ & & & & 77.50 & $4.000 E-7$ & & 30.00 & $1.056 \mathrm{E}+19$ & 6.944 & & \\
\hline Cycle: $8400 \mathrm{nM}$ & & & & 67.46 & $4.000 \mathrm{E}-7$ & & 30.00 & $1.056 E+19$ & 6.425 & & \\
\hline Cycle: 9800 nM & & & & 72.70 & $8.000 E-7$ & & 30.00 & $1.056 E+19$ & 6.738 & & \\
\hline Cycle: $101600 \mathrm{nM}$ & & & & 65.75 & $1.600 \mathrm{E}-6$ & & 30.00 & $1.056 \mathrm{E}+19$ & 0.8639 & & \\
\hline
\end{tabular}

B

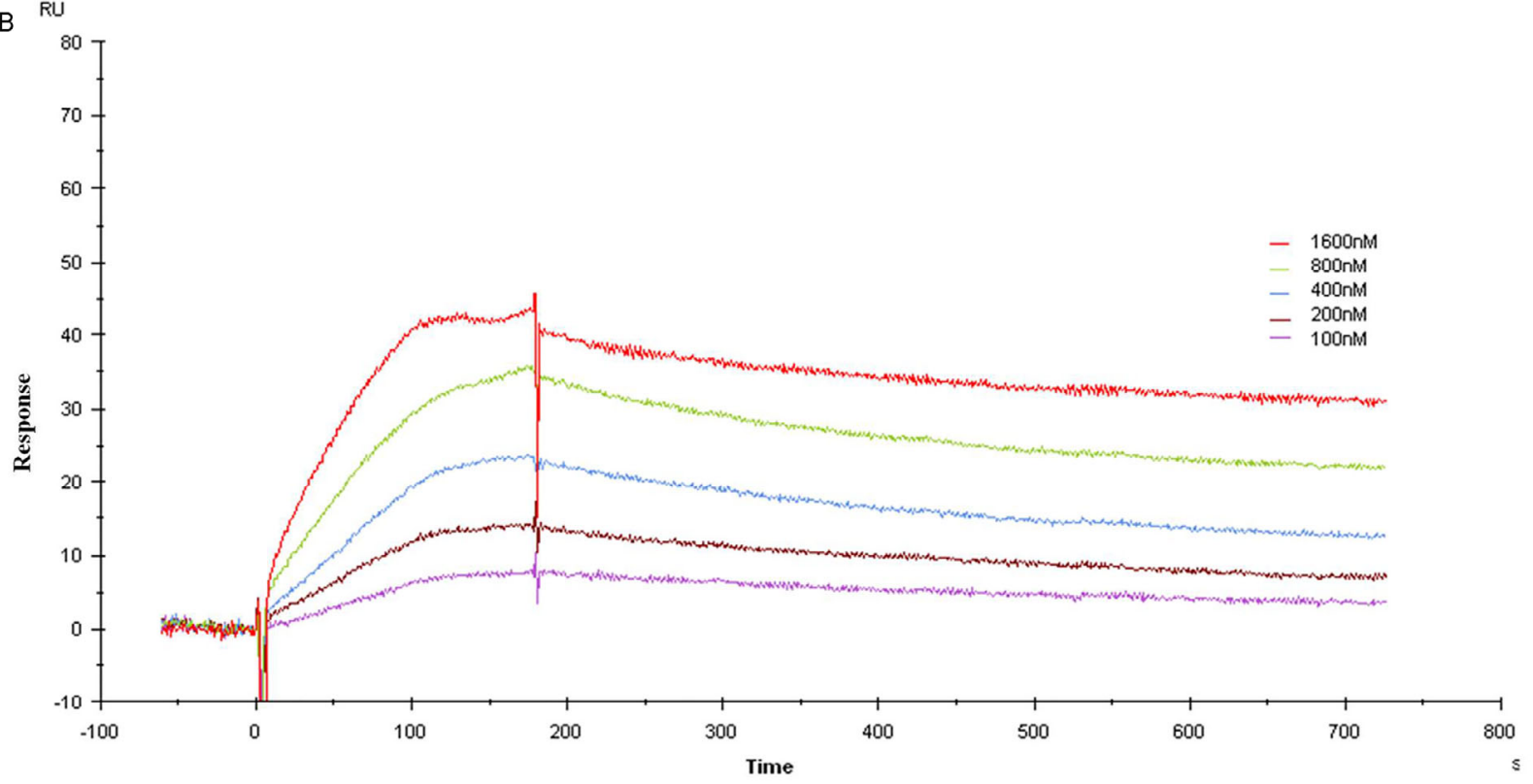

\begin{tabular}{|c|c|c|c|c|c|c|c|c|c|c|c|}
\hline Quality Control Report & Residuals $\mathrm{P}$ & arameters & & & & & & & & & \\
\hline \multirow[t]{2}{*}{ Curve } & ka (1/Ms) & $\operatorname{kd}(1 / \mathrm{s})$ & KD (M) & Rmax (RU) & Conc (M) & tc & Flow (ul/min) & kt (RU/Ms) & RI (RU) & $\mathrm{Chi}^{\mathbf{2}}\left(\mathrm{RU}^{2}\right)$ & U-value \\
\hline & $1.325 \mathrm{E}+4$ & $7.888 \mathrm{E}-4$ & $5.953 E-8$ & & & $1.340 E+16$ & & & & 4.56 & 3 \\
\hline Cycle: $12100 \mathrm{nM}$ & & & & 32.85 & $1.000 \mathrm{E}-7$ & & 30.00 & $4.162 E+16$ & 1.259 & & \\
\hline Cycle: $13200 \mathrm{nM}$ & & & & 33.77 & $2.000 E-7$ & & 30.00 & $4.162 E+16$ & 2.668 & & \\
\hline Cycle: $14400 \mathrm{nM}$ & & & & 35.09 & $4.000 \mathrm{E}-7$ & & 30.00 & $4.162 E+16$ & 3.252 & & \\
\hline Cycle: $15400 \mathrm{nM}$ & & & & 34.49 & $4.000 E-7$ & & 30.00 & $4.162 E+16$ & 2.751 & & \\
\hline Cycle: $16800 \mathrm{nM}$ & & & & 40.15 & $8.000 E-7$ & & 30.00 & $4.162 E+16$ & 2.190 & & \\
\hline Cycle: $171600 \mathrm{nM}$ & & & & 44.98 & $1.600 \mathrm{E}-6$ & & 30.00 & $4.162 E+16$ & -1.150 & & \\
\hline
\end{tabular}

Figure 8 Affinity test of scFv to ZnT8 N/C fusion protein. A, Affinity of scFv-C27 to N/C fusion protein; B, Affinity of scFv-C22 to N/C fusion protein. 


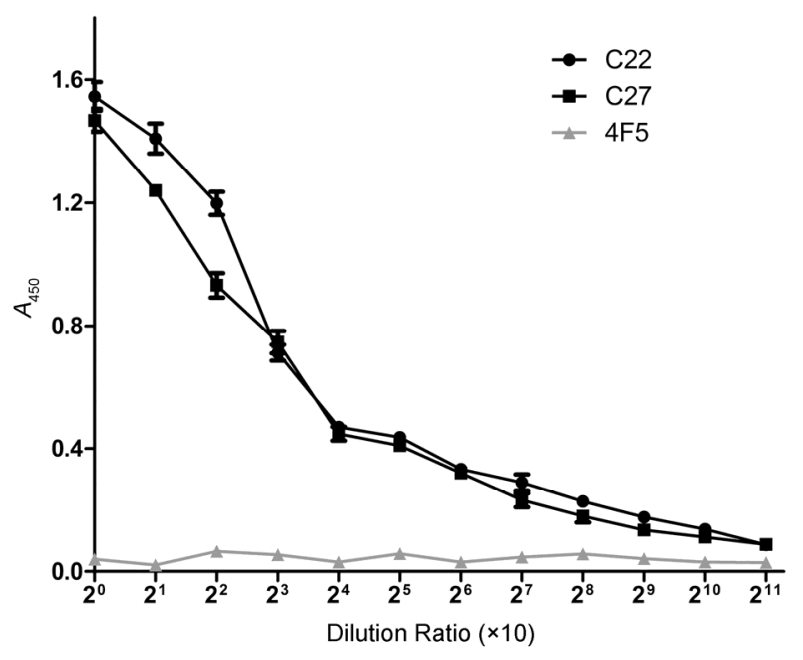

Figure 9 Binding capacity of scFv to $\mathrm{C}$ terminal dimer protein measured by ELISA. C terminal dimer protein was coated on the ELISA plate with $0.5 \mu \mathrm{g} \mathrm{well}{ }^{-1}$. The scFvs used as primary antibody were diluted from 1:10 to 1:20480 by serial dilution. HRP-conjugated anti-HA antibody was used as secondary antibody.

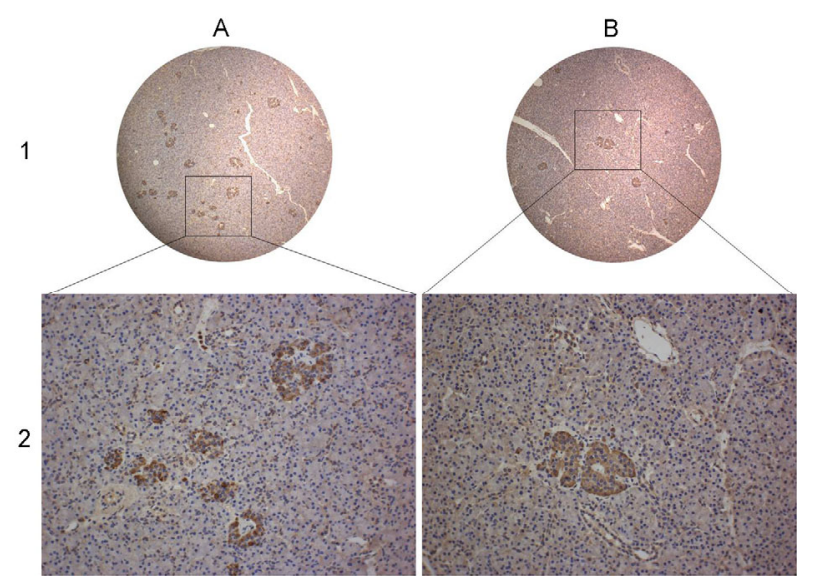

Figure 10 Immunohistochemical reaction to ZnT8 in the human pancreas. $\mathrm{ScFv}$ were used as primary antibody, Rabbit anti-HA tag was used as second antibody, HRP-conjugated anti-Rabbit antibody was used as third antibody. A, Islet cells detected by $\mathrm{C} 27$. B, Islet cells detected by $\mathrm{C} 22$. Row 1, ×40 magnification; row 2, ×200 magnification.

demonstrating high affinity and specificity will enable us to address the questions relating to the role of $\mathrm{ZnT} 8$ in T1D pathogenesis, and also provide the basis for developing satisfactory diagnostics and therapeutics, such as CAR-Treg, which could be used to treat or alleviate the disease.

\section{MATERIALS AND METHODS}

\section{Cloning and expression of recombinant $\mathrm{ZnT}$}

The ZnT8 N/C fusion protein construct (1-74aa, 268-369 aa) was made by combining a $\mathrm{N}$ terminal (1-74 aa) PCR product generated with the forward primer $\mathrm{ZF}$ and a reverse primer LR and a C terminal (268-369 aa) PCR product generated with a forward primer LF and reverse primer CR (Table 2) from a plasmid contains full length of human ZnT8 (Slc30A8) ORF (Sino Biological Inc, HG11621-M). The products were gel purified, mixed and reamplified with the $\mathrm{ZF}$ and $\mathrm{CR}$ primers to generate an N/C fusion sequence.

The ZnT8 C terminal dimer with one Arg325Trp mutation was amplified using the forward primer $\mathrm{CF}$ and the reverse primer CR (Table 2) from the plasmid donated by Barbara Davis Center for Childhood Diabetes, University of Colorado at Denver and Health Sciences Center, USA. The $\mathrm{C}$ terminal dimer with one Arg325Trp mutation consisted two of C terminal, first 268-369 had Arg at position 325 and the second Trp at 325 . The two $\mathrm{C}$ terminals were linked by the sequence encoding for a short peptide $(\mathrm{Gu}$ et al., 2011).

The target gene was cloned into pcold II vector (Biovector pcold II ) with Sac I and Xba I (Takara) and then transformed into E. coli BL21 (DE3). The positive clones were selected and identified by DNA sequencing.

The verified clones were cultured in LB medium with $100 \mu \mathrm{g} \mathrm{mL}^{-1}$ Ampicillin at $37^{\circ} \mathrm{C}$ with further induction by 1 mmol L ${ }^{-1}$ isopropyl- $\beta$-D-thiogalactoside (IPTG) for $24 \mathrm{~h}$ at $15^{\circ} \mathrm{C}$ when the optical density $600\left(A_{600}\right)$ reached 1.0 . The bacteria can be preserved at $-80^{\circ} \mathrm{C}$ after centrifugation at $10,000 \times g$ for $15 \mathrm{~min}$ at $4^{\circ} \mathrm{C}$.

\section{Protein purification}

The bacteria were resuspended in binding buffer (Table 3) and sonicated on ice by ultrasonic homogenizer. The supernatant was filtrated with hydrophilic polyethersulfone membrane $(0.22 \mathrm{~mm}$, Millipore) after centrifugation at $10,000 \times g$ for $30 \mathrm{~min}$. The supernatant was stored at $4{ }^{\circ} \mathrm{C}$ for further experiments. A HisTrap ${ }^{\mathrm{TM}}$ chromatography was used to purify the protein. The target protein was then eluted by elution buffer (Table 3 ). The eluted protein was dialyzed in dialysis buffer (Table 3) supplemented with $4 \mathrm{~mol} \mathrm{~L}^{-1}$ urea at $4{ }^{\circ} \mathrm{C}$ and renew half of the liquid volume with dialysis buffer (Table 3 ) every 4 to 6 hours until the urea concentration below to $0.125 \mathrm{~mol} \mathrm{~L}^{-1}$.

\section{Construction of phage display scFv library from T1D patients' peripheral blood}

PBMC were isolated from 50 newly diagnosed T1D patients according to the World Health Organization criteria. Serum ZnT8A levels were analyzed by immunoprecipitated radioactivity as described earlier (Gu et al., 2011). All samples were collected with appropriate informed consent. We amplified VH and VL genes by RT-PCR using a group of specific constant region primers (Barbas et al., 2004). After spliced the $\mathrm{scFv}$ fragments generated by overlapping PCR, we ligated them into pComb3XSS phagemid. Then we introduced the ligations into competent $E$. coli XL1-Blue by electroporation. The library was rescued and amplified by VCSM13 helper phage. 
Table 2 List of primers for the construction of the recombinant ZnT8 gene ${ }^{\text {a) }}$

\begin{tabular}{cl}
\hline Primer & \multicolumn{1}{c}{ Sequence } \\
\hline ZF & 5'-ACGAGCTCCATCATCATCATCATC ATATGGAGTTTCTTGAAAGAAC-3' \\
LR & 5'-GAGTAAGATGGAGAAGTCCTTGAGTTTCCACTTGGCATAG-3' \\
LF & 5'-CTATGCCAAGTGGAAACTCAAGGACTTCTCCATCTTACTC-3' \\
CR & 5'-GCTCTAGAGTCACAGGGGTCTTCA-3' \\
CF & 5'-ACGAGCTCCATCATCATCATCATCATAAGGACTTCTCCATCTTACTC-3' \\
\hline
\end{tabular}

a) The primers ZF and LR are for the cloning of ZnT8 $\mathrm{N}$ terminal gene; the primers LF and CR are for the cloning of ZnT8 $\mathrm{C}$ terminal gene; the primers $\mathrm{ZF}$ and CR are for the cloning of ZnT8 N/C fusion gene; the primers CF and CR are for the cloning of ZnT8 C terminal dimer gene

Table 3 List of buffers

\begin{tabular}{ll}
\hline \multicolumn{1}{c}{ Buffer } & \multicolumn{1}{c}{ Buffer preparation(-L) } \\
\hline Binding buffer & $\mathrm{NaH}_{2} \mathrm{PO}_{4} \cdot 2 \mathrm{H}_{2} \mathrm{O} 1.56 \mathrm{~g}, \mathrm{Na}_{2} \mathrm{HPO}_{4} \cdot 12 \mathrm{H}_{2} \mathrm{O} 3.58 \mathrm{~g}, \mathrm{NaCl} 29.2 \mathrm{~g}$, Imidazole 1.36 g, Urea 480.5 g $(\mathrm{pH}=7.5)$ \\
Elution buffer & $\mathrm{NaH}_{2} \mathrm{PO}_{4} \cdot 2 \mathrm{H}_{2} \mathrm{O} 1.56 \mathrm{~g}, \mathrm{Na}_{2} \mathrm{HPO}_{4} \cdot 12 \mathrm{H}_{2} \mathrm{O} 3.58 \mathrm{~g}, \mathrm{NaCl} 29.2 \mathrm{~g}$, Imidazole 34 g, Urea 480.5 g (pH=7.5) \\
Dialysis buffer & $\mathrm{NaH}_{2} \mathrm{PO}_{4} \cdot 2 \mathrm{H}_{2} \mathrm{O} 1.56 \mathrm{~g}, \mathrm{Na}_{2} \mathrm{HPO}_{4} \cdot 12 \mathrm{H}_{2} \mathrm{O} 3.58 \mathrm{~g}, \mathrm{NaCl} 29.2 \mathrm{~g}$, Imidazole 1.36 g (pH=7.5) \\
Blocking buffer & $5 \%$ Milk in PBS \\
\hline
\end{tabular}

\section{Panning and expression of anti-ZnT8 scFv}

The purified ZnT8 N/C fusion protein was coated onto ELISA plates for phage bio-panning. The screening procedures and bacteria culture as well as transformation were operated as described elsewhere (Zhang et al., 2013). After four rounds of selection, E. coli XL1-Blue infected with phage were plated on agar plates and incubated overnight at $37^{\circ} \mathrm{C}$. Single bacterial colonies were picked and tested by phage-ELISA. The positive colonies were sequenced and analyzed through compared with the human immunoglobulin sequences (IMGT Database) (Ehrenmann et al., 2010; Lefranc et al., 2015).

Positive scFv-phagemids were extracted from E. coli XL1-Blue colonies and transformed into non-suppressor $E$. coli Top10F'. The verified clones were cultured in SB medium with $100 \mu \mathrm{g} \mathrm{mL}^{-1}$ Ampicillin and $20 \mathrm{mmol} \mathrm{L}^{-1} \mathrm{MgCl}_{2}$ at $37^{\circ} \mathrm{C}$ for $8 \mathrm{~h}$ and then induced by $1 \mathrm{mmol} \mathrm{L}^{-1}$ IPTG for $24 \mathrm{~h}$ at $37^{\circ} \mathrm{C}$. The bacteria were preserved at $-80^{\circ} \mathrm{C}$ after centrifugation at $10,000 \times g$ for $15 \mathrm{~min}$ at $4^{\circ} \mathrm{C}$.

\section{SDS-PAGE and Western blotting}

To identify recombinant ZnT8 proteins and scFvs, separated proteins were transferred onto polyvinylidene fluoride (PVDF) membrane (Millipore) after electrophoresis in $12 \%$ SDS-PAGE. After blocked the membranes by blocking buffer for $2 \mathrm{~h}$ (Table 3), horseradish peroxidase (HRP)conjugated anti-His antibody was added (1:4000) and incubated for $1 \mathrm{~h}$. The $0.05 \%$ PBST was used in washing procedure three times for $15 \mathrm{~min}$ between every two steps. Protein bands were visualized using ECL buffer (Millipore, WBKLS0500).

To identify the binding ability of scFv to the ZnT8 N/C fusion protein, the scFv was used as primary antibody and the HRP-conjugated goat anti-HA (Genscript) was used as second antibody. The bacteria transformed with negative plasmid were used as negative control.

\section{Affinity test of anti-ZnT8 scFvs}

The affinity of $\mathrm{scFv}$ to $\mathrm{ZnT}$ 8 N/C fusion protein was tested using BiacoreX100 at Suzhou BioTop Technical Service Co.,Ltd.

\section{ELISA assay}

The bioactivity of ZnT8 N/C fusion protein was detected by commercial ZnT8A (Abbiotec). N/C fusion protein was coated onto ELISA plates with different concentration range from $0.1 \mu \mathrm{g}$ to $1.6 \mu \mathrm{g}$ per well and incubated overnight at $4^{\circ} \mathrm{C}$. Each well was blocked with blocking buffer (Table 3 ) at $4^{\circ} \mathrm{C}$ overnight. Blocked wells were briefly rinsed with $0.05 \%$ PBST and incubated of commercial ZnT8A with 1:500 dilutions in blocking buffer and incubation at $37^{\circ} \mathrm{C}$ for $2 \mathrm{~h}$. Rabbit serum were used as negative control. Unbound antibodies were removed by washing 3 times with $0.05 \%$ PBST. HRP-conjugated goat anti-Rabbit were added with 1:2000 diluted in blocking buffer (Table 3) and incubation at $37^{\circ} \mathrm{C}$ for $2 \mathrm{~h}$. Wells were washed four times prior to color development.

To identify the binding ability of scFv to ZnT8, we coated the $C$ terminal dimer protein onto ELISA plates with 0.5 $\mu \mathrm{g}$ per well and incubated overnight at $4^{\circ} \mathrm{C}$. Each well was blocked with blocking buffer (Table 3 ) at $4^{\circ} \mathrm{C}$ overnight. Then incubated $\mathrm{scFv}$ antibodies doubling diluted from 1:10 to $1: 20480$ in blocking buffer at $37^{\circ} \mathrm{C}$ for $2 \mathrm{~h}$. ScFv $4 \mathrm{~F} 5$ (Zhang et al., 2013) produced in our lab was used as negative control. Unbound antibodies were removed by washing 3 times with $0.05 \%$ PBST. HRP-conjugated goat anti-HA were added with 1:2000 dilution in blocking buffer (Table 3) and incubation at $37^{\circ} \mathrm{C}$ for $2 \mathrm{~h}$. Wells were washed four times prior to color development.

\section{Immunohistochemical analysis}

The function of the scFv was tested by immunohistochemistry. Human pancreas paraffin sections $(4 \mu \mathrm{m})$ were depar- 
affinized and antigen retrieval performed in $10 \mathrm{~m} \mathrm{~mol} \mathrm{~L}^{-1}$ citrate buffer ( $\mathrm{pH}$ 6.0) for $15 \mathrm{~min}$ at $121^{\circ} \mathrm{C}$. After blocking with $3 \%$ bovine serum albumin (BSA), the sections were incubated with $\mathrm{scFv}$ at $4^{\circ} \mathrm{C}$ overnight and the with rabbit anti-HA antibody at $4^{\circ} \mathrm{C}$ for $12 \mathrm{~h}$. For immunoperoxidase detection, HRP-conjugated anti-rabbit antibody was used. Images were captured using confocal microscopy.

Compliance and ethics The author(s) declare that they have no conflict of interest.

Acknowledgements This work has been supported by National Natural Science Foundation of China (81070622, 81370939), Provincial Six Talent Foundation of Jiangsu (2010-022), Municipal Science and Technology Foundation of Nanjing (009010684) and A Project Funded by the Priority Academic Program Development of Jiangsu Higher Education Institutions (PAPD, JX10231801).

B arbas, C.F., Burton, D.R., Scott, J.K., and Silverman, G.J. (2004). Phage display: a laboratory manual (CSHL Press).

Brenner, M.K., and Heslop, H.E. (2010). Adoptive T cell therapy of cancer. Curr Opin Immunol 22, 251-257.

Cheadle, E.J., Gornall, H., Baldan, V., Hanson, V., Hawkins, R.E., and Gilham, D.E. (2014). CAR T cells: driving the road from the laboratory to the clinic. Immunol Rev 257, 91-106.

Chimienti, F., Devergnas, S., Favier, A., and Seve, M. (2004). Identification and cloning of a beta-cell-specific zinc transporter, ZnT-8, localized into insulin secretory granules. Diabetes 53, 2330-2337.

Chimienti, F., Devergnas, S., Pattou, F., Schuit, F., Garcia-Cuenca, R., Vandewalle, B., Kerr-Conte, J., Van Lommel, L., Grunwald, D., Favier, A., and Seve, M. (2006). In vivo expression and functional characterization of the zinc transporter ZnT8 in glucose-induced insulin secretion. J Cell Sci 119, 4199-4206.

Dang, M., Rockell, J., Wagner, R., Wenzlau, J.M., Yu, L., Hutton, J.C., Gottlieb, P.A., and Davidson, H.W. (2011). Human type 1 diabetes is associated with $\mathrm{T}$ cell autoimmunity to zinc transporter 8 . J Immunol 186, 6056-6063.

Ehrenmann, F., Kaas, Q., and Lefranc, M.P. (2010). IMGT/3DstructureDB and IMGT/DomainGapAlign: a database and a tool for immunoglobulins or antibodies, T cell receptors, MHC, IgSF and MhcSF. Nucleic Acids Res 38, D301-307.

Elinav, E., Adam, N., Waks, T., and Eshhar, Z. (2009). Amelioration of colitis by genetically engineered murine regulatory $\mathrm{T}$ cells redirected by antigen-specific chimeric receptor. Gastroenterology 136, 1721-1731.

Fransson, M., Piras, E., Burman, J., Nilsson, B., Essand, M., Lu, B., Harris, R.A., Magnusson, P.U., Brittebo, E., and Loskog, A.S. (2012). $\mathrm{CAR} /$ FoxP3-engineered T regulatory cells target the CNS and suppress EAE upon intranasal delivery. J Neuroinflammation 9, 112.

Gu, Y., Zhang, M., Chen, H., Wang, Z., Xing, C., Yang, H., Xu, X., Liu, Y., Zhou, Z., Yu, L., Hutton, J., Eisenbarth, G., and Yang, T. (2011). Discordant association of islet autoantibodies with high-risk HLA genes in Chinese type 1 diabetes. Diabetes Metab Res Rev 27, 899-905.

Hasholzner, U., Stieber, P., Meier, W., and Lamerz, R. (1997). Value of HAMA--determination in clinical practice--an overview. Anticancer Res 17, 3055-3058.

Kawasaki, E. (2012). ZnT8 and type 1 diabetes. Endocr J 59, 531-537.

Kawasaki, E., Tanaka, M., Miwa, M., Abiru, N., and Kawakami, A. (2014). Novel enzyme-linked immunosorbent assay for bivalent ZnT8 autoantibodies. Acta Diabetol 51, 429-434.

Kawasaki, E., Uga, M., Nakamura, K., Kuriya, G., Satoh, T., Fujishima, K., Ozaki, M., Abiru, N., Yamasaki, H., Wenzlau, J.M., Davidson,
H.W., Hutton, J.C., and Eguchi, K. (2008). Association between anti-ZnT8 autoantibody specificities and SLC30A8 Arg325Trp variant in Japanese patients with type 1 diabetes. Diabetologia 51, 2299-2302.

Kohler, G., and Milstein, C. (1975). Continuous cultures of fused cells secreting antibody of predefined specificity. Nature 256, 495-497.

Lefranc, M.P., Giudicelli, V., Duroux, P., Jabado-Michaloud, J., Folch, G., Aouinti, S., Carillon, E., Duvergey, H., Houles, A., Paysan-Lafosse, T., Hadi-Saljoqi, S., Sasorith, S., Lefranc, G., and Kossida, S. (2015). IMGT(R), the international ImMunoGeneTics information system(R) 25 years on. Nucleic Acids Res 43, D413-422.

MacDonald, K.G., Hoeppli, R.E., Huang, Q., Gillies, J., Luciani, D.S., Orban, P.C., Broady, R., and Levings, M.K. (2016). Alloantigen-specific regulatory $\mathrm{T}$ cells generated with a chimeric antigen receptor. J Clin Invest 126, 1413-1424.

McCafferty, J., Griffiths, A.D., Winter, G., and Chiswell, D.J. (1990). Phage antibodies: filamentous phage displaying antibody variable domains. Nature 348, 552-554.

Overbeck, S., Uciechowski, P., Ackland, M.L., Ford, D., and Rink, L. (2008). Intracellular zinc homeostasis in leukocyte subsets is regulated by different expression of zinc exporters ZnT-1 to ZnT-9. J Leukoc Biol 83, 368-380.

Richter, M., and Daquillard, F. (1980). Marked enhancement of antibody synthesis following immunization with antigen bound to host lymphocytes. A potential treatment of patients with allergy. Ann Allergy 44, 152-157.

Seve, M., Chimienti, F., Devergnas, S., and Favier, A. (2004). In silico identification and expression of SLC30 family genes: an expressed sequence tag data mining strategy for the characterization of zinc transporters' tissue expression. BMC Genomics 5, 32.

Skarstrand, H., Krupinska, E., Haataja, T.J., Vaziri-Sani, F., Lagerstedt, J.O., and Lernmark, A. (2015). Zinc transporter 8 (ZnT8) autoantibody epitope specificity and affinity examined with recombinant $\mathrm{ZnT} 8$ variant proteins in specific ZnT8R and ZnT8W autoantibody-positive type 1 diabetes patients. Clin Exp Immunol 179, 220-229.

Skarstrand, H., Lernmark, A., and Vaziri-Sani, F. (2013). Antigenicity and epitope specificity of ZnT8 autoantibodies in type 1 diabetes. Scand J Immunol 77, 21-29.

Ustinova, J., Belitskin, D., Juronen, E., Zusinaite, E., Utt, M., and Uibo, R. (2013). Characterization of monoclonal ZnT8-specific antibody. Front Immunol 02.

Weijers, R.N. (2010). Three-dimensional structure of beta-cell-specific zinc transporter, ZnT-8, predicted from the type 2 diabetes-associated gene variant SLC30A8 R325W. Diabetol Metab Syndr 2, 33.

Wenzlau, J.M., Frisch, L.M., Gardner, T.J., Sarkar, S., Hutton, J.C., and Davidson, H.W. (2009). Novel antigens in type 1 diabetes: the importance of ZnT8. Curr Diab Rep 9, 105-112.

Wenzlau, J.M., Juhl, K., Yu, L., Moua, O., Sarkar, S.A., Gottlieb, P., Rewers, M., Eisenbarth, G.S., Jensen, J., Davidson, H.W., and Hutton, J.C. (2007). The cation efflux transporter ZnT8 (Slc30A8) is a major autoantigen in human type 1 diabetes. Proc Natl Acad Sci USA 104, 17040-17045.

Wenzlau, J.M., Liu, Y., Yu, L., Moua, O., Fowler, K.T., Rangasamy, S., Walters, J., Eisenbarth, G.S., Davidson, H.W., and Hutton, J.C. (2008). A common nonsynonymous single nucleotide polymorphism in the SLC30A8 gene determines ZnT8 autoantibody specificity in type 1 diabetes. Diabetes 57, 2693-2697.

Xu, X., Gu, Y., Bian, L., Shi, Y., Cai, Y., Chen, Y., Chen, H., Qian, L., Wu, X., Xu, K., Mallone, R., Davidson, H.W., Yu, L., She, J., Zhang, M., and Yang, T. (2016). Characterization of immune response to novel HLA-A2-restricted epitopes from zinc transporter 8 in type 1 diabetes. Vaccine 34, 854-862.

Zhang, X., Qi, X., Zhang, Q., Zeng, X., Shi, Z., Jin, Q., Zhan, F., Xu, Y., Liu, Z., Feng, Z., and Jiao, Y. (2013). Human 4F5 single-chain Fv antibody recognizing a conserved HA1 epitope has broad neutralizing potency against H5N1 influenza A viruses of different clades. Antiviral Res 99, 91-99

Open Access This article is distributed under the terms of the Creative Commons Attribution License which permits any use, distribution, and reproduction in any medium, provided the original author(s) and source are credited. 